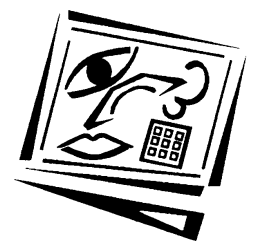

\title{
Towards a smart community: Rethinking the strategic use of ICTs in teaching and learning
}

\author{
Colin Baskin \\ James Cook University \\ Michelle Barker and Peter Woods \\ Griffith University
}

In response to continuing pressures for change and reform in the higher education sector, this paper outlines and develops a 'smart community' model for developing the strategic use of information and communication technologies (ICTs) in university teaching and learning. It presents the 'smart community' as a viable metaphor and model for articulating and managing integrated training, education, consultancy and research initiatives for staff and students alike, and details its application at a specific faculty and regional setting.

\begin{abstract}
The concept of a smart community is to develop innovative partnerships among community institutions and organisations, governments, local business and a range of private sector interests, to take full advantage of the digital economy. A smart community is considered to be one that has developed the means and methods to extract economic, social and cultural benefits from electronic networks. This paper identifies how one university has managed to pilot innovative services and applications to create new value and transform the 'rhythms' of its local, host community through the use of ICTs.
\end{abstract}

\section{Introduction: Why focus on ICTs?}

In his book Mega Universities and Knowledge Media, Daniel (1996:4) suggests that a new university would be required every week in order to sustain the emerging participation rates in higher education. Given the implausibility of infrastructure growth of this kind and scope, higher education providers have enlisted the potential of new information and communication technologies (ICTs) to extend and support the administrative, research, teaching and learning functions of the university. As universities grapple with identifying a future role for ICTs, the level of practice by current academics has not (at large) delivered the 'critical 
mass' (Rogers 1995) of practitioners required to make adoption of new learning technologies self sustaining. Academics are more likely to adapt ICTs for personal use than for enhancing teaching and learning (DETYA, 2000; Brennan, Miller \& Moniotte, 2001). At the global level, the literature reports a perceived lack of leadership in 'growth oriented learning opportunities' within the higher education sector (Macchiusi \& Trinidad, 2000:2; Hagner \& Schneebeck, 2000:1). Many 'academic managers' have become bogged down with restructure behaviours at the expense of 'innovation uptake'. This leads to a learning system imbalance, wherein technology investment outstrips investment in people, and "where information technology rather than 'pedagogy' drives curriculum reform" (Celsi \& Wolfinbarger 2001:308).

At the heart of this paper therefore, is the concern that existing models for integrating ICTs into the higher education curriculum fail to adequately address the broader learning needs of the university community. At the enterprise level, Macchiusi and Trinidad (2000:2) point to a lack of uniformity in computer hardware and software systems, even where an institution has adopted a commercial Learning Management System (LMS) solution. Hagner and Schneebeck (2000:2) point to the diversity of 'faculty' views on the role and value of ICTs at a time when "technological change has removed the spatial security of academic institutions by opening up and redefining the core concept of the delivery of learning". Vogel and Klassen (2001:105) suggest that with the use of ICTs the role of the faculty member is not eliminated, but rather "their resource base gets larger and more varied as technology extends in a plurality of new directions". To extend this analysis, Dabbagh (2002:2) details that preparation time for face to face teaching requires 6-7 hours per week, compared to its online counterpart requiring 18-19 hours per week. Not only are teaching staff required to be doing more, but they are required to do it differently and often in dual or multiple delivery modes.

The limitations of 'teacher bandwidth' have never been more acutely felt in an era where academic development involves the adaptation of an entirely new working identity (Taylor, 1999). Institutional attempts to come to terms with issues of resourcing, funding and rewarding the adaptation of ICTs in teaching generally recognise that each institution has different and often fixed views, of the changing educational landscape. In response to continuing pressures for change and reform in the higher education sector, this paper outlines and develops a 'smart community' model for developing the strategic use of ICTs in university teaching and learning. It presents the 'smart community' as a viable metaphor and model for articulating and managing integrated training, education, consultancy and research initiatives for staff and students alike. 


\section{The smart community: Collaborative action learning}

While many Australian universities lay claim to offering 'learning resources' online, there is great variation in what is meant by an online resource. Some are taking the approach of 'web enhancing' existing materials, while other providers are choosing to 'web mount' and package learning materials for greater economy of delivery. There exists an extensive body of literature which features these approaches to utilising ICT resources within a university teaching and learning context (e.g. Lambier, 2002; Kearsley, 2002; Blasi \& Heinecke, 2000; Boalch 1996). Fewer universities, however, are redeveloping learning approaches to take full advantage of the pedagogical opportunities provided by new and emerging technologies, particularly in relation to action learning and action research processes and how these articulate to a 'smart community' model.

Smart communities aim to develop innovative partnerships among community institutions and organisations, governments, local business and a range of private sector interests to take full advantage of the digital economy. The smart community is one that has developed the means and methods to extract economic, social and cultural benefits from electronic networks. This often means piloting innovative services and applications, thus creating new value and transforming the 'rhythms and cycles' by which the community lives, works, develops, produces and reproduces. Its application to knowledge networks and industries is significant.

The 'smart' role that action learning and action research can play in learning, professional development and organisational change have been well documented in the literature (Zuber-Skerritt 1996; Bourner \& Flowers 1999; Limerick, Passfield \& Cunnington 1994). Action research involves team research by practitioners 'into their own practice'. For this reason, action learning and team based approaches to learning in an online environment provide a compelling framework for cultivating a dynamic community of practice. Action learning entails a simple but effective cyclical structure, which involves participants in the active processes of planning, acting, observing and reflecting. These are the 'rhythms' by which individuals and communities continually renew themselves through learning processes. Learning becomes a mutually developmental process between communities and individuals, one that stems well beyond the mere socialisation of practice.

Many ICT development efforts (within and outside Australian university settings) have not planned for an integrated 'smart community' model. There have been abortive community trials of the concept by Telstra at Gungahlan (Canberra), by Optus at Springfield (South-west of Brisbane), 
and by Delfin (Lendlease) in conjunction with Bond University (Varsity Lakes Community) at Robina on Queensland's Gold Coast. Unlike a traditional classroom setting, where everyone is learning the same thing, participants in an integrated 'smart' community contribute in a variety of inter-dependent ways to the enterprise of the community and in engaging with others within that enterprise. The doors of the classroom are quite literally thrown open, and the walls torn down. In place of the classroom, stands a community portal or gateway. The community portal and the online environment become a way of organising community relations, while providing the context in which learning can be demonstrated through active participation by community members (research, evaluation and consultancy processes). In this spirit, the Teaching and Learning Business Index (TALBI Portal) was conceived as a means of bringing the functions of the 'academy' to the community (and those of the community to the academy) in a way that the each could understand, appreciate and access.

\section{The Teaching and Learning Business Index}

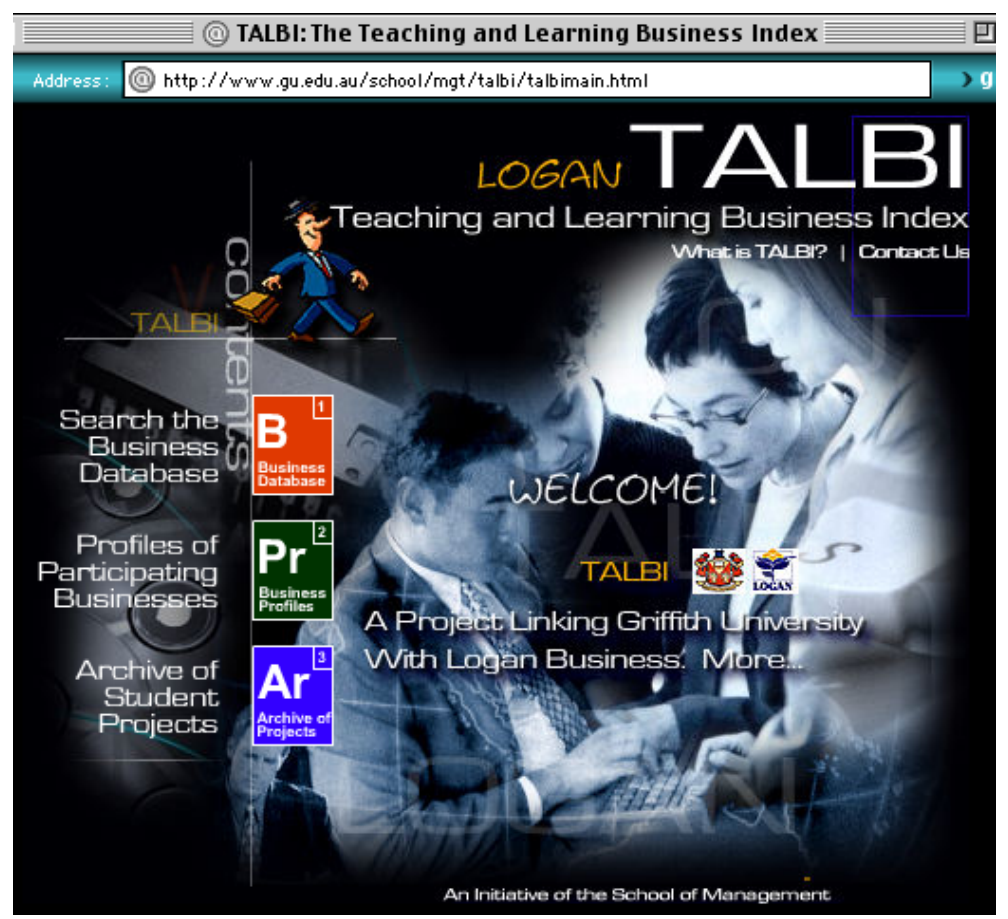

Figure 1: TALBI Portal Interface

http: / / www.gu.edu.au/school/mgt/talbi/talbimain.html 
TALBI is the acronym for the Teaching and Learning Business Index, a School of Management portal and project aimed at providing a comprehensive online index of organisational and industry resources in the Logan district of Queensland, Australia. At the heart of TALBI is an electronic action learning index and database that can be used by businesses, educators, students and researchers to tie local industry more closely with learning and research programs within the School of Management. It provides a practical focus to learning and skills development within a community, practitioner and organisational context.

As a learning resource, the TALBI index features:

- 3500 local organisations interested in acting as mentors and contacts for student learning;

- Profiles and overviews of these organisations;

- The types of activities and projects being undertaken within participating organisations;

- Further areas for study and student involvement; and

- An archive of student projects and research endeavours within participating organisations.

The index integrates and focuses staff teaching practices with applied research and investigative projects in a flexible learning mode, while documenting, describing and archiving student experiences of industry . The goal of this approach has been to improve knowledge and understanding of the nature, functions, management practices, marketing strategies and information systems of local organisations, through more practical application, and in doing so to achieve greater community and industry input/ relevance to the learning programs of the host school. The leverage of social relationships (with local community) is incorporated into the portal in order to maximise learner engagement through action learning. In this way, learning becomes the enterprise of the total community. In practice, this means:

1. The learning activities set around TALBI require mutual engagement, with other students, staff and with the listed host organisations.

2. The designated learning tasks challenge student frameworks, yet 'provoke' them to explore new terrain within their communities and disciplines. The action learning component lends itself well to mentoring practices, hence the involvement of industry and academic mentors.

3. The cycle of learning is continuous; participants (staff, student and industry) are able to build a commitment to each other, and to TALBI as an organising resource. 


\section{TALBI as strategic architecture}

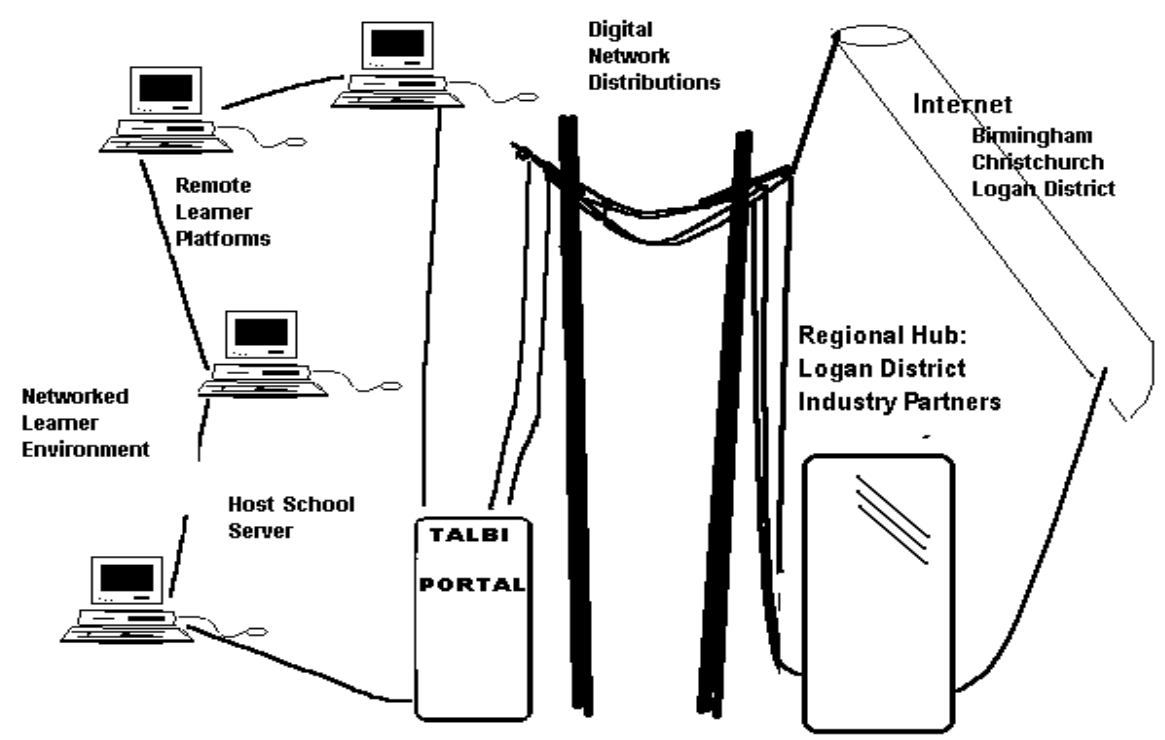

Figure 2: TALBI as a strategic learning architecture

The TALBI Index is utilised in a number of subjects within the degree programs of the host school (local and extra-local), with the primary focus being the Applied Management Project, a third year undergraduate industry practicum in which students focus on a group research project hosted by a chosen organisation. A subsequent third year undergraduate management subject, entitled The Reflective Practitioner, requires students to return to their project organisations to review the success (or otherwise) of their project. An introductory first year management subject and second year management decision making and operations management subjects also use the portal.

Collaborative group work and action learning underpins curriculum efforts to 'implement' a strong industry, enterprise and graduate focus on teamwork, and to explore local ways in which organisations (through learning) are continuously moving towards internal structures based on work teams or groups. The classroom remains an effective place to learn about the traditional theoretical aspects of socio-technical work design, quality circles, TQM and their corresponding models of human and intellectual capital. The workplace, as part of the 'smart community' architecture, is that part of the 'networked' environment peopled by global 
students, academics and industry partners that is able to transform classroom theory into a practical and experiential context.

The development of the TALBI portal creates an opportunity to broker ownership of the smart community model between existing Schools within the Business Faculty, conjointly recognising the transformative roles of information systems vis-à-vis management (and vice versa). The TALBI portal provides evidence of the innovations possible through closer collaboration in the combined teaching and research expertise of the host schools, integrating Internet technologies with the strategic management of organisations in business education to produce graduates equipped to engage in electronic commerce (Celsi and Wolfinbarger, 2001). This type of practitioner based learning takes training beyond the use of software programs to the strategic use of Internet technology in management. In short, the TALBI portal has become a vehicle to enable participants to theorise about businesses large and small, non-profit organisations, the needs of the community and the role and challenges facing governments local and national. These applications go beyond the more common business student focus on the Internet as a simple search and report tool.

\section{Transforming teaching and learning relations}

Teaching does not 'cause' learning, but teachers and teaching tools such as TALBI become resources for learning in much more complex ways in an ICT 'smart' community. The value of TALBI lies in its capacity to enable teaching, learning, research and consultancy to interact so as each becomes a structuring resource for the other. In the past business schools have been among the first to adopt emerging ICTs, but have been among the slowest to appropriate these beyond the level of stand alone applications (Brennan et al 2001). To the extent that teaching, learning and research are linked in practice, the linkage is not one of cause and effect but of resources and negotiation. Opening one learning pathway involves opening access to others. The second part of this paper documents how learner and teacher roles 'evolved' through the interaction, exchange, and reflective opportunities the online environment offered. In particular, it will elaborate the situated learning experiences of thirty-three graduating students, and of the small cohort of academics who jointly supervised and assessed their final year industry projects, along with host organisational supervisors. The program was very successful for all three cohorts of participant, particularly the learners:

- $>50 \%$ of the 68 students who participated in the TALBI project in the final year of their degree had secured 'positions' prior to graduation.

- $>30 \%$ of students had more than one 'job' option. 
- Each participating student had acquired and relied upon 'demonstrable' industry experience obtained through TALBI project in seeking graduate work.

- Each student graduated with a published (and archived) project report.

- Each student obtained consensual referees from their industry project.

- No student 'failed' their industry placement; and

- Female students obtained higher industry and academic rankings than male students thus enhancing career and graduate prospects.

\section{Extending bandwidth: Putting the 'smart' in student learning}

The strategic architecture underpinning TALBI stresses the growing importance of 'self accessed' and 'student directed' learning as part of the shift in higher education from content based learning to process based learning (Vogel \& Klassen, 2001). Wenger (1998) describes this as interplay between the 'planned and emergent' functions of pedagogy, insofar as teaching can predict but not control the outcomes of learning. In choosing organisations for industry practicum, the availability of a self accessed database gives the student greater autonomy and freedom to select a suitable host organisation, a compatible organisational supervisor, and a relevant area of interest. This choice is enabled through the pedagogical intentions of the TALBI database, in the form of search protocols, site specific standards, software applications and managed application lists and processes. The TALBI database provides organisational profiles that enable students to make a more informed choice of research topic, focus and host supervisor.

\section{Industry partner feedback}

An assessment scale featuring twenty-two professional competencies was devised in conjunction with participating industry partners (Table 1 below). These items were designed to address six competency areas:

- Professional attitude/ approach (items 1-5)

- Programming/project planning (items 6-9)

- Leadership/instructional skills (items 10-14)

- Communication skills (items 15-19)

- Feedback and evaluation (items 20-22)

- Employment potential (summarised as 'yes', 'no', or 'maybe')

Items 1-22 were completed using a five point Likert scale (see example below). Additionally, sections were provided for qualitative responses to the questions: 'What are the student's main strengths?' 'In which areas 
should the student work to further training and development?', and; 'What issues need to be considered to improve the quality of the particular project for your organisation?'

Table 1: Frequencies and percentages of items in the Professional Readiness Scale

\begin{tabular}{|c|c|c|c|c|c|c|c|c|c|c|}
\hline \multirow[t]{2}{*}{ Item } & \multicolumn{2}{|c|}{$\begin{array}{l}\text { Not } \\
\text { applic- } \\
\text { able }\end{array}$} & \multicolumn{2}{|c|}{$\begin{array}{l}\text { Below } \\
\text { perform- } \\
\text { ance }\end{array}$} & \multicolumn{2}{|c|}{ Average } & \multicolumn{2}{|c|}{$\begin{array}{l}\text { Above } \\
\text { average }\end{array}$} & \multicolumn{2}{|c|}{$\begin{array}{l}\text { Out- } \\
\text { standing }\end{array}$} \\
\hline & $\mathrm{N}$ & $\%$ & $\mathrm{~N}$ & $\%$ & $\mathrm{~N}$ & $\%$ & $\mathrm{~N}$ & $\%$ & $\mathrm{~N}$ & $\%$ \\
\hline $\begin{array}{l}\text { Demonstrates } \\
\text { professional skills }\end{array}$ & 2 & $6.1 \%$ & 3 & $9.1 \%$ & 5 & $15.2 \%$ & 10 & $30.3 \%$ & 13 & $39.4 \%$ \\
\hline Arrives promptly & 2 & $6.1 \%$ & 2 & $6.1 \%$ & 13 & $39.4 \%$ & 0 & 0 & 16 & $48.5 \%$ \\
\hline Is dependable & 2 & $6.1 \%$ & 1 & $3.0 \%$ & 5 & $15.2 \%$ & 13 & $39.4 \%$ & 12 & $36.4 \%$ \\
\hline Works independently & 2 & $6.1 \%$ & 1 & $3.0 \%$ & 2 & $6.1 \%$ & 11 & $33.3 \%$ & 17 & $51.5 \%$ \\
\hline Effective team member & 10 & $30.3 \%$ & 1 & $3.0 \%$ & 2 & $6.1 \%$ & 7 & $21.2 \%$ & 13 & $39.4 \%$ \\
\hline $\begin{array}{l}\text { Plans thoroughly and } \\
\text { realistically }\end{array}$ & 2 & $6.1 \%$ & 1 & $3.0 \%$ & 5 & $15.2 \%$ & 12 & $36.4 \%$ & 13 & $39.4 \%$ \\
\hline Is innovative & 0 & 0 & 3 & $9.1 \%$ & 8 & $24.2 \%$ & 11 & $33.3 \%$ & 11 & $33.3 \%$ \\
\hline Shows initiative & 1 & $3.0 \%$ & 2 & $6.1 \%$ & 7 & $21.2 \%$ & 7 & $21.2 \%$ & 16 & $48.5 \%$ \\
\hline $\begin{array}{l}\text { Uses time effectively } \\
\text { and efficiently }\end{array}$ & 7 & $21.2 \%$ & 1 & $3.0 \%$ & 5 & $15.2 \%$ & 13 & $39.4 \%$ & 5 & $15.2 \%$ \\
\hline $\begin{array}{l}\text { Understands client } \\
\text { needs }\end{array}$ & 4 & $12.1 \%$ & 1 & $3.0 \%$ & 6 & $18.2 \%$ & 13 & $39.4 \%$ & 9 & $27.3 \%$ \\
\hline $\begin{array}{l}\text { Displays knowledge } \\
\text { and understanding }\end{array}$ & 3 & $9.1 \%$ & 0 & 0 & 5 & $15.2 \%$ & 20 & $60.6 \%$ & 5 & $15.2 \%$ \\
\hline $\begin{array}{l}\text { Ability to motivate and } \\
\text { enthuse others }\end{array}$ & 7 & $21.2 \%$ & 3 & $9.1 \%$ & 5 & $15.2 \%$ & 13 & $39.4 \%$ & 5 & $15.2 \%$ \\
\hline $\begin{array}{l}\text { Coordination of group } \\
\text { of clients }\end{array}$ & 18 & $54.5 \%$ & 0 & 0 & 1 & $3.0 \%$ & 10 & $30.3 \%$ & 2 & $6.1 \%$ \\
\hline $\begin{array}{l}\text { Adjusts to } \\
\text { circumstances }\end{array}$ & 5 & $15.2 \%$ & 1 & $3.0 \%$ & 8 & $24.2 \%$ & 9 & $27.3 \%$ & 9 & $27.3 \%$ \\
\hline Relates well to staff & 1 & $3.0 \%$ & 1 & $3.0 \%$ & 5 & $15.2 \%$ & 14 & $42.4 \%$ & 9 & $27.3 \%$ \\
\hline Relates well to clients & 17 & $51.5 \%$ & 0 & 0 & 0 & 0 & 9 & $27.3 \%$ & 4 & $12.1 \%$ \\
\hline Oral communication & 1 & $3.0 \%$ & 2 & $6.1 \%$ & 4 & $12.1 \%$ & 12 & $36.4 \%$ & 14 & $42.4 \%$ \\
\hline Written communication & 2 & $6.1 \%$ & 0 & 0 & 4 & $12.1 \%$ & 11 & $33.3 \%$ & 15 & $45.5 \%$ \\
\hline Team member & 11 & $33.3 \%$ & 1 & $3.0 \%$ & 2 & $6.1 \%$ & 4 & $12.1 \%$ & 13 & $39.4 \%$ \\
\hline Seeks feedback & 1 & $3.0 \%$ & 2 & $9.1 \%$ & 6 & $18.2 \%$ & 15 & $45.5 \%$ & 8 & $24.2 \%$ \\
\hline $\begin{array}{l}\text { Response to advice and } \\
\text { assistance }\end{array}$ & 2 & $6.1 \%$ & 0 & 0 & 4 & $12.1 \%$ & 16 & $48.5 \%$ & 11 & $33.3 \%$ \\
\hline $\begin{array}{l}\text { Identifies weaknesses } \\
\text { in own performance }\end{array}$ & 3 & $9.1 \%$ & 1 & $3.0 \%$ & 4 & $12.1 \%$ & 16 & $48.5 \%$ & 7 & $21.2 \%$ \\
\hline
\end{tabular}


Data detailed here features a convenience sample of 33 respondents (17 female and 16 male) presented as frequencies and percentages (Table 1). Both academic and industry supervisors were invited to rate students according to the following five point scale.

- A/5 outstanding performance

- $\mathrm{B} / 4$ above average performance

- $\mathrm{C} / 3$ average performance

- $\mathrm{D} / 2$ below performance

- X/1 not applicable

Industry supervisors assessed a significant majority of students (19 [57.6\%]) completing their industry practicum as "work ready", chisquared $(2, N=33)=8.91, p=.01$ (Figure 3$)$. For those not deemed "work ready" (8 [24.2\%]; 6 [18.2\%] were deemed as "maybe" ready), completion of a follow up subject, aptly named the 'Reflective Practitioner', encouraged them to engage with supervisor feedback, revisit their practicum project, and reconstruct different processes and outcomes in conjunction with their project supervisors.

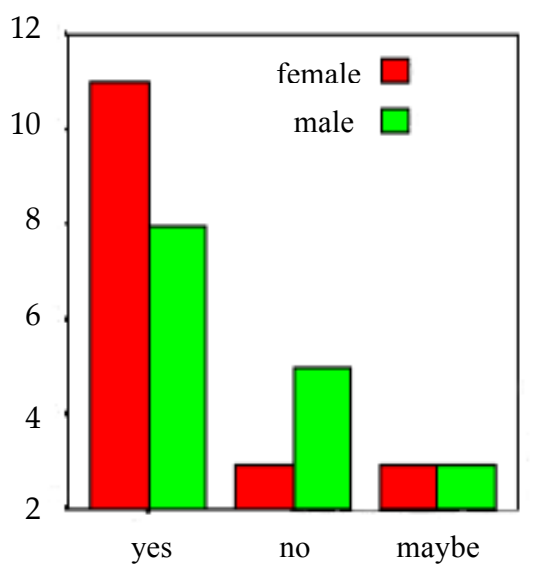

Figure 3: Employment potential

The design and development of the TALBI portal gives the business students of the Logan campus, and the organisations of the Logan district, their own localism, their own regimes of competence, and even, in the case of ongoing projects, their own generational encounters. On the TALBI web site, the student projects archive helps to preserve valuable information that is useful to a range of community members - similar businesses, market researchers, policy and decision makers as well local planning and lobby groups. This 'organisational memory system' (OMS) spans the 
Logan business community, and "functions to provide a means by which knowledge from the past is brought to bear on present activities, thus resulting in increased levels of effectiveness" for the community (Stein and Wass 1995:95).

The TALBI portal draws the university and the local community together in very compelling ways. Industry supervisors also provided valuable feedback to academic staff about the currency of existing degree programs, and industry views of the types of 'learner capital' students were accumulating.

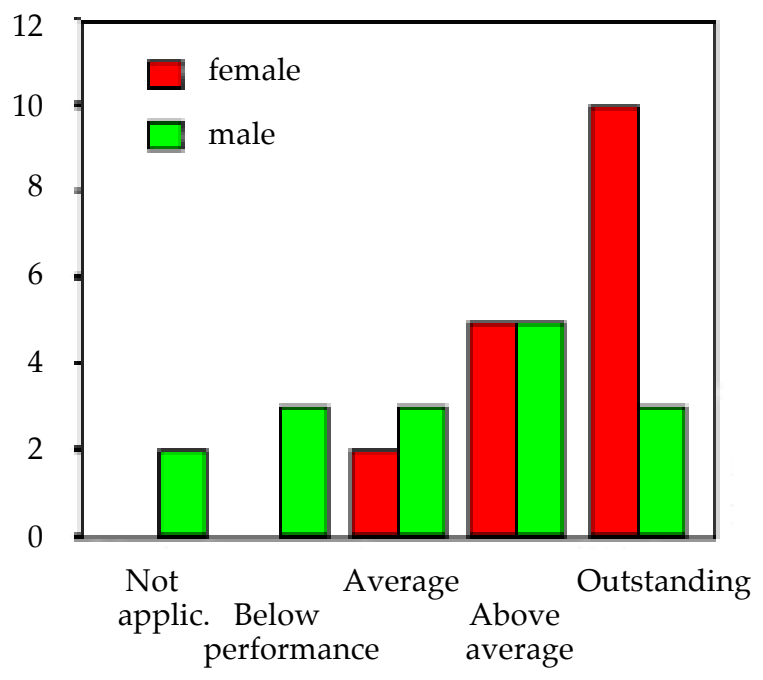

Figure 4: Actively seeks opportunities

Between group comparisons indicate that female students were seen by industry supervisors to more actively seek opportunities to demonstrate workplace competence (Figure 4), and to extend situated learning opportunities. Similarly, industry supervisors reported their collective perception that females had more effective written, oral and electronic communications skills than their male counterparts. As indicated below (Figure 5), females were perceived to be more flexible, and to be more committed to developing a 'team' ethic (Figure 6) through a commitment to building team membership through group (synchronous and asynchronous) communications. 


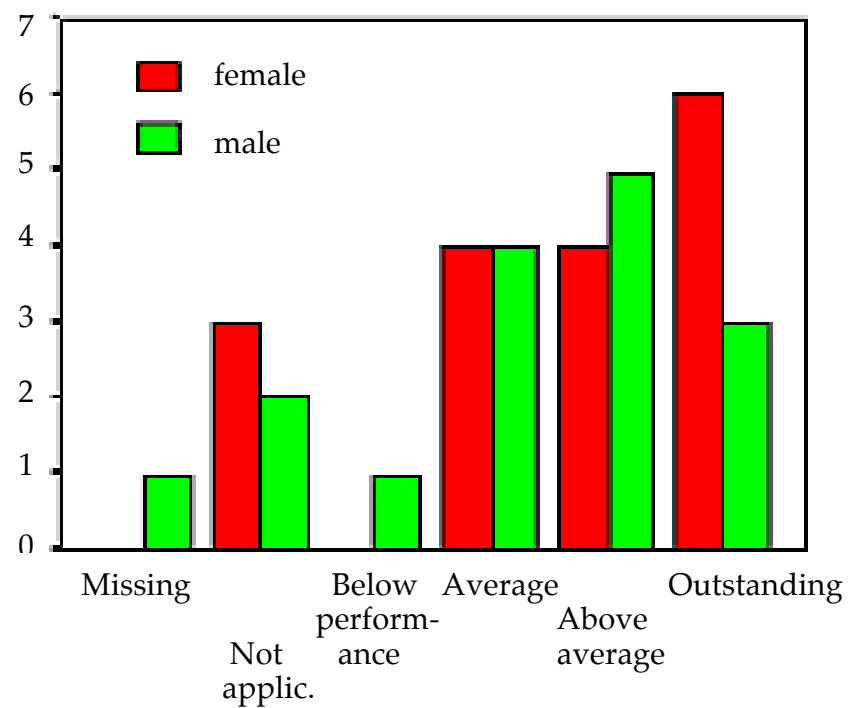

Figure 5: Adjust to change/ difficulty

Suffice to say, on all but one of the twenty-two items surveyed (understanding of client needs) female students were rated by industry supervisors as more 'professionally ready' than their male counterparts.

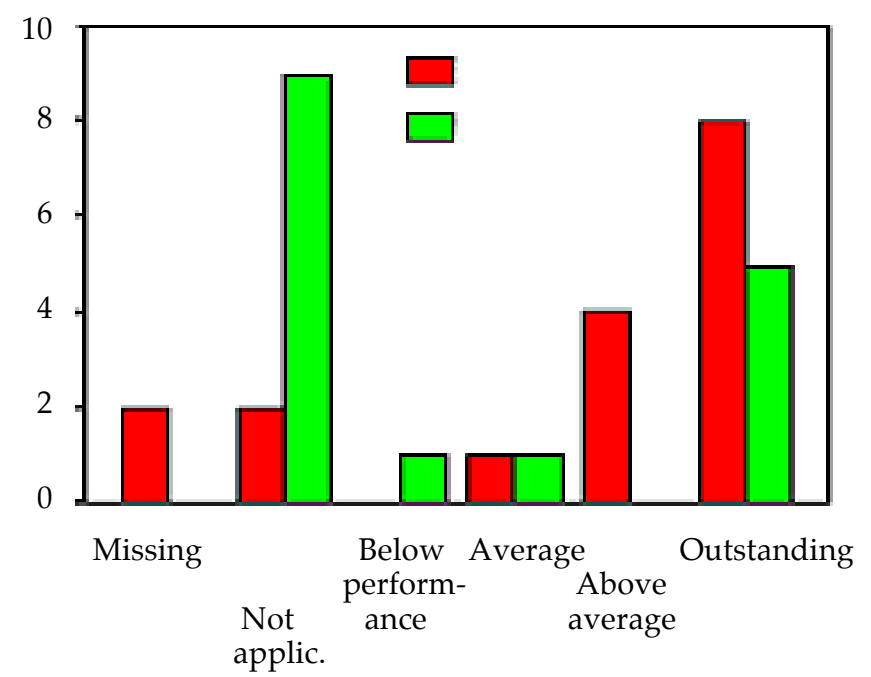

Figure 6: Teamwork/membership 
Cross group comparisons show that a significant (with Bonferroni adjusted alpha $=.01$ ) number of students were scored highly for professional attitude/ approach $(M=3.47, S D=1.17), t(18)=12.92, p<.01$ (95\% scoring between 2.91 and 4.04$)$, programming/project planning $(M=$ $3.50, S D=1.16), t(15)=12.12, p<.01(95 \%$ scoring between 2.88 and 4.12$)$, leadership/instructional skills $(M=3.67, S D=1.09), t(17)=14.34, p<.01$ (95\% scoring between 3.13 and 4.21$)$, communication skills $(M=3.71, S D=$ 1.11), $t(16)=13.83, p<.01(95 \%$ scoring between 3.14 and 4.27$)$, and responding to feedback and evaluation $(M=3.64, S D=1.12), t(10)=10.78$, $p<.01$ (95\% scoring between 2.88 and 4.39). In other words, the vast majority of students performed at least 'average' in all categories, with the performance usually leaning towards 'above average'. Considering how many students were reported as 'work ready', this data would indicate that most students were considered not only work ready but were also assessed as having above average workplace skills by their host organisational supervisors.

The TALBI portal has enabled participating students to become 'better connected to their world' (Nkombo-Muaka et.al, 1999) through interactive learning technologies. This accessibility also provides students with the opportunity and context to have their work recognised by both peers and organisations as archived records of student and industry collaborations. TALBI facilitates deep transformative experiences that involve new dimensions of identification and negotiability, new forms of membership and multi-membership by locating students in a broader community of relational practice. The TALBI portal, and the Smart Community Model present a way to use the web in a collaborative teaching and learning environment to open trajectories of participation to all community members.

\section{What do academic staff say?}

The relationship between information systems and organisational development as entities within schools of business has been labelled distant due to often divergent approaches and solutions to problems (Coghlan and McDonagh 2001). This distance extends to business education, reinforcing a perceived divide between the two academic communities. The pervasive influence of information systems within organisations, however, has gradually made the divide a barrier to effectiveness in areas such as change management, systems analysis, and decision making and management control.

Initiatives to bridge the divide come together in the TALBI portal. To this point, this paper has documented aspects of learner engagement with the TALBI resource as reported by industry partners, but the story of teacher 
engagement is also one of transformation. The reflective processes assigned to TALBI articulate directly to an experiential learning cycle as defined by Kolb (1984). This cycle is embedded in the adjacent diagram (Figure 7). It demonstrates how design aspects of the TALBI portal integrate the reflective processes of practitioner based learning across the four domains of the learning community.

\section{Environmental factors}

Process

management focus

\section{Environmental factors}

Need for

role definition

Need for problem definition

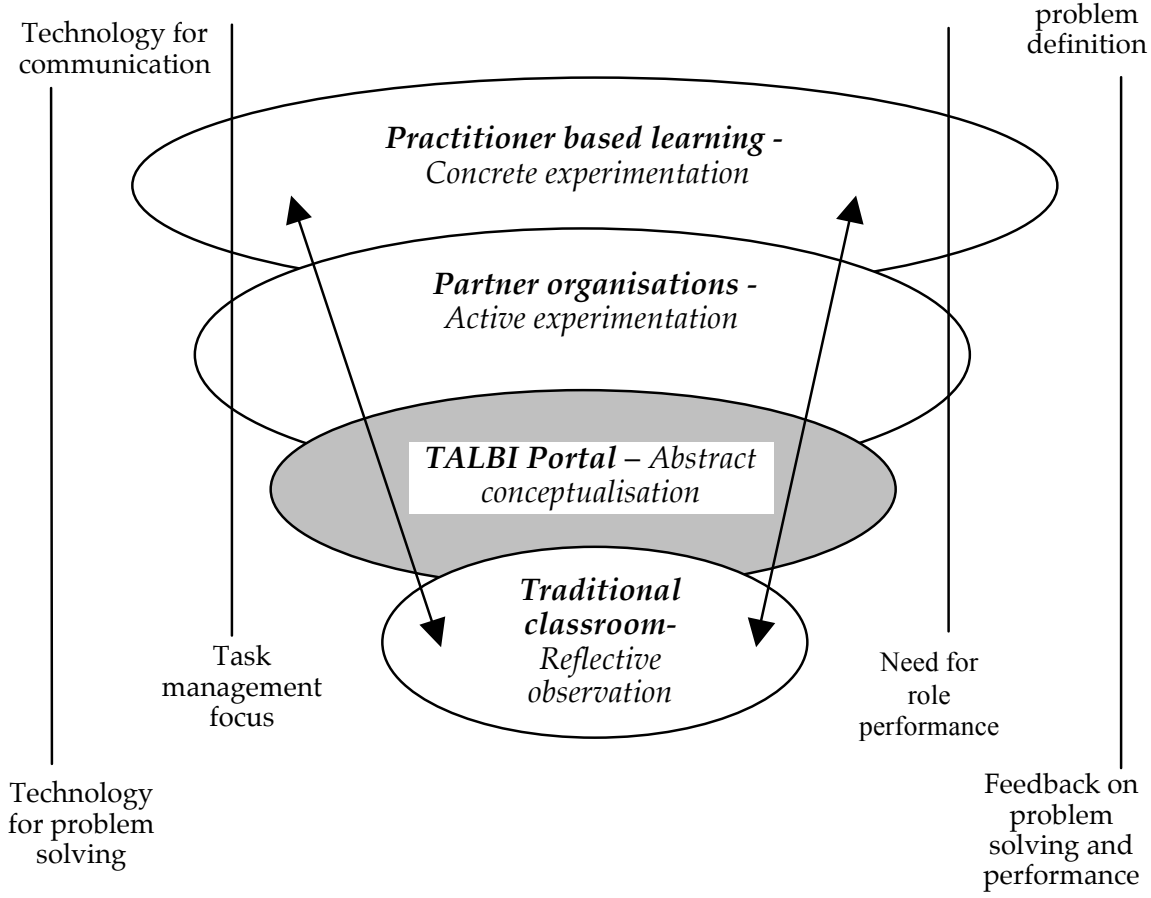

Figure 7: The Smart Community Model

The environmental factors associated with each of Kolb's (1984) domains (reflective observation, abstract conceptualisation, active experimentation, and concrete experience) are mediated by technology, task and role performance, and feedback characteristics. As the learner moves through the dynamic of practitioner based learning, she/he does so in a way that brings them closer to definitive aspects of situated practice. Not only does the TALBI portal engage her/him in concrete learning activities, but it extends these activities to incorporate reflective processes that enable each party to engage other learning communities (future, potential, prospective 
employers, and prospective clients) about activities that have consequences beyond their immediate teaching and learning boundaries. The reflective process is essentially one of 'alignment'. Reflection about learning enables the learner to extend 'boundary processes' and to 'align' with new and emerging interests (Wenger, 1998:274). It opens opportunities for multi-membership, and provides access to styles and discourses of broader constellations. Reflection is also about collaborative alignment, in so far as the learner is inducted into a form of apprenticeship with 'fellow' learners and collaborators through the act of 'participation'.

In the case documented here, a team of eight academics supervised sixtyeight (68) students across forty organisational sites. In some cases the host organisation required a single disciplinary solution (i.e. soft systems solution; health and safety audit), but in many cases, particularly the not for profit organisations, the solutions sought were multi-disciplinary and ongoing. This meant the formations of staff teams of academic supervisors whose task it was to work closely with industry supervisors as vanguards of student welfare and project integrity. The discipline was not the safe haven to which academic supervisors came to hide, but was the edge which gave their background and discipline momentum and meaning.

"I felt myself at the coalface of my field ... working vicariously through my students in a host of organisational settings". (Lecturer - Information Systems)

"I was out of the office and meeting people. People were calling me. I suddenly realised that this was an opportunity for me as much as for the students. I discovered a whole new network of resources and potential resources as guest speakers and in a way I found a new sense of relevance as an academic". (Lecturer - Management)

"I found it difficult to work with other lecturers on team supervision (as) I am the only Industrial Relations staff member here. I felt I was successful however at bringing my discipline to local organisations in a way that increased everyone's understanding of what we do as practitioners". (Lecturer - IR)

For some academics the 'kickback' from their involvement in the 'smart community' exercise was both immediate and rewarding.

"I am co-publishing a paper with Geoff (student). It has been peer reviewed and it looks like we will accidentally get a publication out of what was a really fortuitous project. For me, I suppose the best news is that I have negotiated one definite, and perhaps two consultancies with local organisations. I am finding my own way forward". (Lecturer - Business Communication) 
"On the back of the contacts we made through TALBI three of us have applied for and won a community grant for $\$ 10,000$ to work with non-profit organisations locally ... Fantastic ... this is seed funding for other initiatives and for targeting consultancies". (Lecturer - Management Decisionmaking)

"This type of teaching is ahead of its time. My school is behind it very much, to the tune that my Head of School is willing to bankroll a dinner for participating organisations, and staff of the Logan Campus. This has made us invaluable to the local community". (Lecturer - Marketing).

The TALBI portal is a demonstration of the power of a collaborative approach, involving the practical use of an information system tool to enhance decision making, organisational analysis, community development and problem solving. The fact that students, staff, industry and community members differed as to their perceptions of which problems needed resolution mattered little - what mattered was the innovative use of ICTs as a collaborative resolution strategy, able to explicate, align and bracket community interests.

\section{Conclusion: Reciprocity and community development}

Reflection, according to Dewey (1916), has to do with an 'intentional endeavour' to discover 'specific connections' between an action and the 'consequences' which result from it. 'Reflection in action' (Schon, 1983:242) is considered a dynamic of adaptive organisations and effective organisational learning systems. TALBI demonstrates how these processes both converge and diverge in an ICT rich environment, allowing student, staff, industry and/or community members to experience reflection in learning and how it can be implemented within and across multiple platforms. In doing so, each community member comes to better understand the potential of information technology, by forming networked alliances which benefit the community as a whole.

Because of their united efforts, this emerging community was able to leverage increased resources to launch projects to further exploit and embed the potential of the ICT infrastructure that was already in place. This is evidence of a community rethink of the strategic role of ICTs in teaching and learning. The active involvement of the 'academe' in the local community (and the reciprocal involvement of the local community at the site of the university) creates a synergy that has allowed each party to build upon the effort of the other. Partnerships between private, public, university, not for profit and community groups are essential to facilitate service delivery at the community level. Yet despite significant advances and reliance on information and communication technologies at the site of the university, there remains a lack of coherent and compelling vision as to 
how universities at large may embrace ICTs to create better outcomes for students, staff, industry and local community groups. Clearly there are emerging clusters forming around common areas of interest such as access to communications infrastructure, e-learning, mature communities, and in the area of business development, that warrants a deeper rethink.

As a postscript to the TALBI initiative, our final contact with this TALBI cohort of projects took place at a community poster presentation in which all involved students, university dignitaries, organisational supervisors and academic supervisors attended. The projects were heralded a huge success by the host organisations. Academic and industry stakeholders met later at the 'community dinner' hosted by the School of Marketing, and in second semester students returned to their host organisations to evaluate the impact of their TALBI project on their host organisations. Long after the classroom had closed for business, the community continued growing 'ever smarter'.

\section{References}

Blasi, L. \& Heinecke, W.F. (2000). From rhetoric `o technology: A transformation from citizens to consumers. In R.A. Cole (Ed), Issues in Web-based Pedagogy: A Critical Primer. London: Greenwood Press.

Boalch, G. (1996). WWW as an educational support medium: An Australian case study. Proceedings AusWeb96.

http:/ / ausweb.scu.edu.au/aw96/educn/boalch/paper.htm

Brennan, L., Miller, J., Moniotte, S. (2001). Herding cats to water: Benchmarking the use of computers in business education. Journal of Education for Business, 76(6), 318-328.

Bourner, T. and Flowers, S. (1999). Teaching and learning methods in higher education: A glimpse of the future. http:/ / www.bbk.ac.uk/asd/Bourne.htm

Celsi, R. and Wolfinbarger, M. (2001). Creating renaissance employees in an era of convergence between information technology and business strategy: A proposal for business schools. Journal of Education for Business, 76(6), 308-312.

Coghlan, D. and McDonagh, J. (2001). Academic formation and IT-enabled change - A conspicuous relationship. Organization Development Journal, 19(1), 21-29.

Dabbagh, N. (2002). Using a web-based course management tool to support faceto-face instruction. The Technology Source, Mar/Apr.

http: / / ts.mivu.org / default.asp?show=article\&id=938

Daniel, J. (1996). Mega Universities and Knowledge Media. London. Kogan Page. 
DETYA (2000). Learning for the Knowledge Society: An Education and Training Action Plan for the Information Economy. Department of Education, Training and Youth Affairs. Canberra. AGPS.

http: / / www.dest.gov.au/schools / publications / 2000/learning.pdf

Dewey, J. (1916). Democracy and education: An introduction to the philosophy of education. New York: Macmillan.

Hagner, P. \& Schneebeck, C. (2000). Engaging the faculty. In C. Barone and P. Hagner (Eds), Technology-enhanced Teaching and Learning: Leading and Supporting the Transformation on Your Campus. Educause Publication.

Kearsley, G. (2002). MEPP: A case study in online education. The Technology Source, Jan-Feb. http: / / ts.mivu.org / default.asp? show=article\&id=935

Kolb, D. (1984). Experiential Learning. Englewood Cliffs: Prentice Hall.

Lambeir, B. (2002). Comfortably numb in the digital era: Man's being as standing reserve or dwelling silently. In M. Peters (Ed), Heidegger, Education and Modernity. Rowman and Littlefield. New York.

Limerick, D., Passfield, R. and Cunnington, B. (1994). Transformational change: Towards an action learning organization. The Learning Organization, 1(2), 29-39.

Macchiusi, L. and Trinidad, S. (2000). Implementing IT at an Australian university: Implications for university leaders. In A. Herrmann and M.M. Kulski (Eds), Flexible Futures in Tertiary Teaching. Proceedings of the 9th Annual Teaching Learning Forum, 2-4 February 2000. Perth: Curtin University of Technology. http: / / lsn.curtin.edu.au/tlf/tlf2000/macchiusi.html

Nkombo-Muuka, G. and Chookole-Bbenkele, E. (1999). Electronic and print publishing of research papers in business: A comparison. Journal of Education for Business, 74(5), 275-278.

Rogers, E. (1995) Diffusion of Innovations. 4th Ed. New York. The Free Press.

Satzinger, J., Garfield, M. and Nagasundaram, M. (1999). The creative process: The effects of group memory on individual idea generation. Journal of Management Information Systems, 15(4), 143-160.

Schon, D. (1983). The Reflective Practioner: How professionals think in action. New York: Harper Collins.

Stein, E. and Zwass, V. (1995). Actualizing organizational memory with information systems. Information Systems Research, 6(2), 85-117.

Taylor, P.G. (1999). Making Sense of Academic Life: Academics, Universities and Change. Buckingham. Open University Press. 
Vogel, D. and Klassen, J. (2001). Technology-supported learning: Status, issues and trends. Journal of Computer Assisted Learning, 17(2), 104-114.

Wenger, E. (1998) Communities of Practice - Learning, Meaning and Identity. Cambridge University Press. Cambridge.

Zuber-Skerritt, O. (1996). Emancipatory action research for organizational change and management development. In O. Zuber-Skerritt (Ed), New Directions in Action Research. Falmer Press, London, pp. 83-104.

\section{Dr Colin Baskin}

Teaching Development, Cairns Campus, James Cook University

Colin.Baskin@jcu.edu.au

Dr Michelle Barker

School of Management, Nathan Campus, Griffith University

M.Barker@griffith.edu.au

Mr Peter Woods

School of Management. Logan Campus, Griffith University

Peter.Woods@griffith.edu.au 